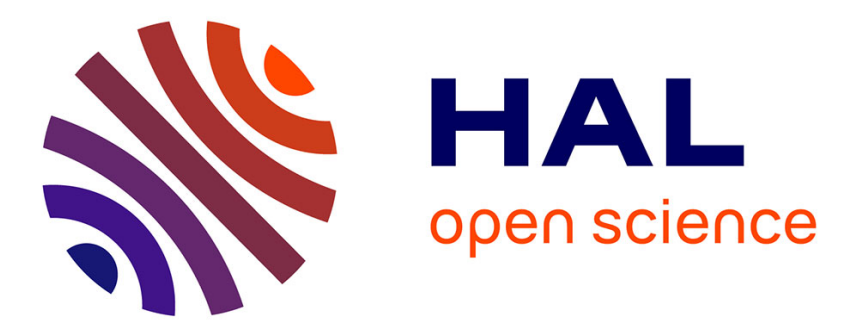

\title{
Health Tourism as an Inducer of Economic and Social Development in Teresina City
}

Átila Lira, Herbert Gonçalves Espuny, Pedro Oliveira costa neto, Reinaldo

De Araújo Lopes

\section{- To cite this version:}

Átila Lira, Herbert Gonçalves Espuny, Pedro Oliveira costa neto, Reinaldo De Araújo Lopes. Health Tourism as an Inducer of Economic and Social Development in Teresina City. IFIP International Conference on Advances in Production Management Systems (APMS), Sep 2016, Iguassu Falls, Brazil. pp.438-444, 10.1007/978-3-319-51133-7_52 . hal-01615801

\section{HAL Id: hal-01615801 \\ https://hal.inria.fr/hal-01615801}

Submitted on 12 Oct 2017

HAL is a multi-disciplinary open access archive for the deposit and dissemination of scientific research documents, whether they are published or not. The documents may come from teaching and research institutions in France or abroad, or from public or private research centers.
L'archive ouverte pluridisciplinaire HAL, est destinée au dépôt et à la diffusion de documents scientifiques de niveau recherche, publiés ou non, émanant des établissements d'enseignement et de recherche français ou étrangers, des laboratoires publics ou privés.

\section{(c)(1)}

Distributed under a Creative Commons Attribution| 4.0 International License 


\title{
Health Tourism as an Inducer of Economic and Social Development in Teresina City
}

\author{
Átila Melo de Lira, Herbert Gonçalves Espuny, Pedro Luiz de Oliveira Costa \\ Neto, and Reinaldo de Araújo Lopes \\ Paulista University, São Paulo, Brazil \\ mestradoua@bol.com.br
}

\begin{abstract}
In recent years, the global growth of the economy contributed to the significant increase of tourism in the world, spreading its concepts in Brazil. There have also grown the related researches in the academic sector, as well as its concern with long life companies, growth in the Northeast region, globalization and other changes occurring in the short term. Thus, this work aims to present how a state among those with lower income per capita in the Federation, as Piauí, has a health care system in its capital which is a benchmark in Northeastern Brazil, influencing positively health tourism. The work deals with issues involving tourism as a product and service, having as a result the existence of a cluster of health in the city of Teresina with economic expression that justifies its importance as a generator of income, employment, science and technology and a promoter of sustainable development in that city.
\end{abstract}

Keywords: Tourism $\cdot$ Health pole $\cdot$ Sustainable development.

\section{Introduction}

According to the World Tourism Organization [1], tourism receipts reach US\$ 919 billion. There was a slowdown in the tourism sector due to the global economic crisis of 2008, which caused some instability in the confidence of agents for future events. However, despite the crisis, to make a comparative analysis of ten years prior to 2010, the foreign exchange earnings from tourism in 2008 (US\$ 857.40 billion) was 92.67\% higher than in 1999 (US\$ 445,00 billion), demonstrating a significant growth in a decade. Also according to the UNWTO [1], between 1999 and 2010, the international flow of tourism in the world grew by $49 \%$, beating the mark of 935 million trips in 2010, an estimated 1.6 billion in 2020. The Figure 1 illustrates the growth of the sector during the period.

The UNWTO researches of 2010 also present important data of the tourism sector in Brazil, indicating that in the same period the foreign exchange earnings more than tripled from US\$ 1.81 billion in 1999 to US\$ 5.92 billion in 2010 . 


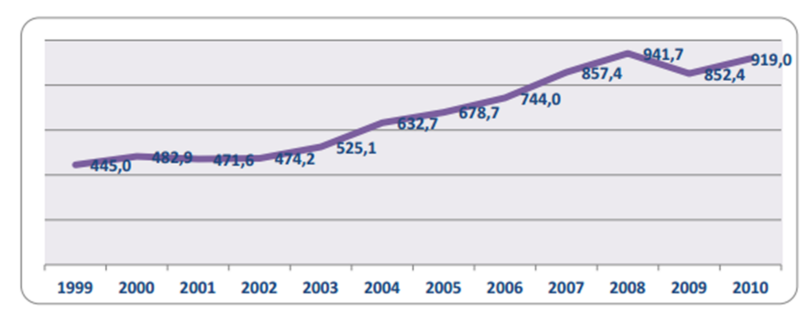

Fig. 1: Growth of the tourism sector (Source: [1])

Contextualizing the city of Teresina, in this article, with about 850,000 inhabitants, Piauí state capital, Brazil, Northeast, one of the poorest in the country, but whose capital emerged as a respectable health pole with qualified service as a result of the entrepreneurial spirit of its main managers. The Health Pole of Teresina (PI) has shown strong growth in recent years, becoming a regional referral center. A first diagnosis made by Piaui Hospitals' Union shows that $30 \%$ of clients served come from six other states of the federation, generating jobs and income for the city [2].

The beginning of the development of a health cluster, with the formation of a supply chain and connected services, bringing benefits in terms of cost reduction, quality improvement, training of skilled labor, capital attraction and generation of employment and income. This benefit extends to the Health Private Network, increasing their participation in services to the population through an investment which reached US\$ 68 million reais in 2011, according to the Medical Union of Piaui

The central objective of this article is to demonstrate the contribution of health tourism as an encouraging instrument for the beginning and the growth of companies as well as a mechanism that contributes to the company to assume more effectively its social function, contributing to improving the quality of life of a particular region and also as immediate growthinducing factor of Teresina.

\section{Definition of Tourism and its Classifications}

Tourism can be focused as a phenomenon that refers to the movement of people within their own country (domestic tourism) or crossing national borders (international tourism). This movement reveals elements such as interactions and individual or team relationships, human understanding, feelings, perceptions, motivations, pressures, satisfaction, the concept of pleasure, etc[3].

According to Castelli [4], the comprehension of the phenomenon of tourism current must necessarily pass through an analysis of the meaning of the trips in the course of history. These, frequently, were moved by economic political and military interests. Nowadays, travels with these same objectives continue to move people from one region to another.

Travelling is an action arising from a context which is inserted into the society at a specific moment in history. It has always been one of the elements of 
economic and social life and, especially, of the world which is inserted. To each type of civilization or society corresponds a way to travel or accept the traveler.

As stated by Wahab [3], the anatomy of the phenomenon of tourism would be basically composed of three elements: the man (human element as the author of the act of tourism), the space (physical element, covered by the act itself), and time (temporal element that is consumed by the journey itself and by staying at the destination). These elements are representative of the conditions of this phenomenon existence.

However, other factors distinguish tourism from the simple act of traveling. Such factors relate mainly to the goals, the temporary nature of displacement, the use of tourist services and equipment and, what would be the most important among them, the concept of pleasure and recreation as fundamental.

Olimpio [5] affirms that a revolution in the traditional concepts of trips was performed by the tourism phenomenon from the middle of the nineteenth century when the Protestant Pastor Thomas Cook inaugurated the first tourist agency in England.

Countries such as Italy, France and Spain, old military powers and colonialists, managed to stabilize their balances of payments in the postwar due to tourism, reaching to the point of this activity is to constitute real industry, with its own public body, specific legislation, which aims to regulate the various aspects of social, economic, commercial and cultural tourism, always aiming at better income and greater expansion of the tourist industry.

\subsection{Factors that Influence Tourist Decisions}

Every person is a tourist in potential, being necessary, however, the action of the tourist trip to characterize as so. For this reason there are some constraints as: the desire (animus) and the possibility [5]. The desire can originate from different causes such as: propaganda, the status, habit, physical convenience, moral or intellectual, seduction, commercial interest or of profit and health. The second constraint involves factors that are beyond the control of man, as: time vacant, money, means of transport, among others.

As the possibility was always easier to exist in the most privileged classes, the concept of tourism is usually bound by luxury. However, with paid vacations, social tourism became easier and popular.

In this way, there are various reasons that people become tourist: business, religious reasons, health, culture, education and pleasure are just a few examples.

According to Arrillaga [6], the needs that tourism satisfy can be very varied, since the subjective causes that determine the tourist trips are as diverse as the needs which the body or the human soul may experience.

The tourist motivations or subjective causes of tourism can be classified into primary and secondary; direct and indirect; proximate and remote; individual and social.

However, the tourist deciding to travel generally has more than one cause, as shown below. 
- Primary and Secondary causes. For example, a person who performs a pilgrimage has, as main cause, the obtaining of a grace of the spiritual order, however, also weighs in its decision the possibility to get to new places, visit the famous monuments, rest, among others.

- Direct and indirect causes. The achievement of a certain journey may occur due to an invitation or the desire to know some locality. However, it can involve indirect causes, such as the habit of travel or the socioeconomic level of the traveler.

- Proximate and remote causes. As an example of proximate cause of a trip, is the propaganda of a travel agent and as remote cause example, the remembrance of a previous trip.

- Individual and social causes. The Individual Causes act in the decision of a person to travel and the Social Causes influence by equal in sectors of the population. As an example of the first, we can mention the practice of a sport and of the second, the fashion or ideological affinities. The particular motivation for health tourism allows to consider it due to primary, direct, proximate and individual causes.

\section{Tourism Classifications}

According to a first general classification according to Andrade [7], the city of Teresina case and its health pole may be classified as a regional receptive nucleus of people for health treatment, and internal, because the temporary flow is typically regional in the country itself. The Table 1 exposes in objective way the more common tourism types.

Table 1: Tourism types classifications (Source: [7])

\begin{tabular}{|l|l|}
\hline Classification & \multicolumn{1}{|c|}{ Description } \\
\hline Vacation & $\begin{array}{l}\text { Vacation configures a guarantee of an intensive tourism, because the se- } \\
\text { quence of days available to leisure and rest. It is one of the highest points } \\
\text { of the profitability of tourism; }\end{array}$ \\
\hline Cultural & $\begin{array}{l}\text { Covers the activities for the satisfaction of artistic emotions, scientific, } \\
\text { training and information in the various existing branches }\end{array}$ \\
\hline Business & $\begin{array}{l}\text { Is the set of activities of travel, accommodation, food and leisure activ- } \\
\text { ities practiced by travelers relating both to commercial and industrial } \\
\text { activities; }\end{array}$ \\
\hline Active sports & $\begin{array}{l}\text { Refer to all the activities of travel with an objective to participate in } \\
\text { sporting events, in the country or abroad; }\end{array}$ \\
\hline Health & $\begin{array}{l}\text { Also known as therapeutic tourism or treatment, refers to the set of } \\
\text { tourist activities to acquire good physical and mental health; }\end{array}$ \\
\hline Religious & $\begin{array}{l}\text { Set of activities that involve visits to the receptive that express mystics } \\
\text { feelings or raise the faith, hope and charity to believers; }\end{array}$ \\
\hline
\end{tabular}


For purpose of this work we will use the typology of health tourism, because that is what happens in some health poles regional throughout Brazil as, for example, the focus of this paper, the case of Teresina. Table 2 presents a tourism form classification.

Table 2: Tourism Form classification (Source: [7])

\begin{tabular}{|l|l|}
\hline Classification & \multicolumn{1}{|c|}{ Description } \\
\hline Individual & $\begin{array}{l}\text { Also known as private tourism or self-financing, refers to the set of ac- } \\
\text { tivities required for planning and travel implementing, without the in- } \\
\text { termediary of travel agencies or tourism entities; }\end{array}$ \\
\hline Organized & $\begin{array}{l}\text { Is the set of tourist activities programed, administered and imple- } \\
\text { mented by tourism agencies, associations, class entities, clubs or another } \\
\text { organization involving a group of people; }\end{array}$ \\
\hline Social & $\begin{array}{l}\text { A type of organized tourism for people of social layers whose rents, } \\
\text { without the help of others, not would allow them to plan a travel. Gener- } \\
\text { ally, concerns the vacation colonies of associations, class entities, compa- } \\
\text { nies or hostels that work with governmental resources or special funds; }\end{array}$ \\
\hline Intensive & $\begin{array}{l}\text { Refers to the set of tourism programs in which people remain hosted in } \\
\text { a single location, even if they set tours and excursions to other places; }\end{array}$ \\
\hline Extensive & $\begin{array}{l}\text { Refers to the hosting and the set of activities in a same core, with dura- } \\
\text { tion of at least three weeks. This method excludes the tours and excur- } \\
\text { sions to other receptive; }\end{array}$ \\
\hline Itinerante & $\begin{array}{l}\text { Involves a series of lodging in different places, consists of visits to the } \\
\text { greatest possible number of receptive cores, on a single trip, with short } \\
\text { stay in the visited places. }\end{array}$ \\
\hline
\end{tabular}

According to the form, you can classify the people who migrate to Teresina for health treatment in individual, because most of the time travelers get to the city with its own resources by regional and interstate bus that cut the city through the various highways in the state.

\section{Tourism Industry}

The internal relationship that exists between tourism and the economic science is always expressed in terms of the contribution of tourism to economic development. Wahab [3] writes that:

"Tourism is a phenomenon that involves the transfer of capital from one country to another through the movement of tourists who go to certain touristic" product" and consume. They are potential consumers of complex goods and services that are offered with a specific goal. The tourism, through the aspects of consumption and investment, affects different sectors of the economic system of a country, and it is believed that its multiplier effect is higher than that observed in other sectors of the economy such as industry. ..." 
Tourism is productive, accurate and determined with specific characteristics, joined to the field of development and commerce. So, depending on the stage of development of a country or a region, it can be considered the first force, ahead of industry and agriculture.

According to data from the Brazilian Tourism Company - Embratur [8], the tourist industry in recent decades has shown representative economic value. This fact is evidenced by the volume of transactions carried out as a result of increased demand for travel and tourism.

The following part of this paper, will discuss some economic concepts that are directly linked to the tourism industry of the real economy of a region.

\subsection{Economic Concepts}

Some economic concepts that influence the study of tourism as an industry are: economic good, utility, economic agents, tourist product, demand and supply of tourism.

As Lage [9] presents, all that is rare and exists in less quantity than needs is an economic good. Thus, because of this lack, something need to be produced, taking the form of goods (materials) or services.

As the consumers cannot get everything they want, they are forced to make choices. Therefore, they may have preference for a given good service but accept a minor amount of another. However, in any situation, consumers act rationally in order to obtain maximum satisfaction from their spending.

\section{Economic and Social Implications of Tourism}

As state by Baptista [10], tourism advantages for a country or a receiving state are:

- Increase of revenues in foreign currency from the sale of goods and services;

- Creation of new sources of revenue in various economic sectors;

- Low investment compared to the revenue stream that it promotes;

- The integration between people of regions, languages, habits and different tastes.

The economic impacts generated by tourism can be classified according to Gunn [9] as : direct impact, known as the total income generated in the tourist sector as a direct result of the variation in spending on these products; indirect impact, the total income generated by the spending of the tourism sectors in goods and services offered in the economy, and induced impact, a result of the direct and indirect impacts of tourism, income levels increase throughout the economy, and that part of this additional income will be spent on goods and services produced domestically. 
5 The implication of health tourism at Teresina city As a result of these impacts related to health tourism in Piaui capital, it is possible to show in an objective way, that an integrated set of these impacts on the local economy, created 15,000 direct jobs and an annual average investment of 80 million reais (approximately US\$22 million, values converted to the exchange of 04.05.2016) order of direct and indirectly related to sectors linked with the area in question. The tourism industry has the positive impact on the economy of a city, according to Andrade [7], by: (i) increased income of the visited place by foreign exchange inflows; (ii) stimulation of investments and creation of new jobs; (iii) the redistribution of wealth between the places of origin and destination.

As negative impacts are mentioned: inflationary pressure, being harmful to the population of the tourist regions, because the high prices in general also affect goods and essential services; high dependence on tourism, making the economy of the region vulnerable to seasonal fluctuations in demand for tourism products; and the social and environmental costs in the tourist areas and residents; So, with these definitions and characteristics of tourism, it is clear the importance and complexity of the tourism for sector in a particular country or region, since it can not only brings capital exchange, but also prosperity to a particular community with regard to professional qualifications, better quality of life with a better performance of the services offered to the population.

\section{Conclusion}

Tourism is an industry with multivariate interests. Bringing the tourist to a particular location has different motivations. A developing region, like the Brazilian Northeast, needs to use all possible ways to seek an economic and socially sustainable development that adds value to their economy. The pursuit of excellence in health services, as demonstrated by the Teresina case, is an economic and social way of doing this, especially in regions waiting fordevelopment.

\section{References}

1. Organização Mundial do Turismo: Conselho de Turismo e Negócios da Fecomercio. Tech. rep. (2011)

2. Prefeitura de Teresina: Agenda 2015 da Prefeitura de Teresina, http://www. teresina.pi.gov.br/

3. Wahab, S.E.A.: Introdução à Administração do Turismo. Pioneira, São Paulo (2008)

4. Castelli, G.: Hospitalidade: A Inovação na Gestão nas Organizações Prestadoras de Serviços. Saraiva, Rio de Janeiro (2010)

5. Olimpio, B.N.: Introdução ao Estudo do Turismo. Atlas, São Paulo (1984)

6. Arrilaga, J.I.d.: Introdução ao Estudo do Turismo. Rio, Rio de Janeiro (2010)

7. Andrade, J.V.: Turismo: Fundamentos e Dimensões. Ática (2008)

8. Baptista, M.: Caderno temáticos da Embratur. Tech. rep. (1991)

9. Lage, B.H.G., Milone, P.C.: Economia do Turismo. Papirus, Campinas (2010)

10. Baptista, M.: Turismo: Gestão Estratégica. Atlas, São Paulo (2004) 